\title{
Genetic diversity in sugarcane varieties in Brazil based on the Ward-Modified Location Model clustering strategy
}

\author{
B.P. Brasileiro ${ }^{1}$, C.D. Marinho ${ }^{1}$, P.M.A. $\operatorname{Costa}^{1}$, E.F.A. Moreira ${ }^{1}$, \\ L.A. Peternelli ${ }^{1}$ and M.H.P. Barbosa ${ }^{2}$ \\ ${ }^{1}$ Departamento de Estatística, Universidade Federal de Viçosa, Viçosa, MG, Brazil \\ ${ }^{2}$ Departamento de Fitotecnia, Universidade Federal de Viçosa,Viçosa, MG, Brazil \\ Corresponding author: C.D. Marinho \\ E-mail: caillet.marinho@yahoo.com.br
}

Genet. Mol. Res. 13 (1): 1650-1660 (2014)

Received April 23, 2013

Accepted September 2, 2013

Published January 17, 2014

DOI http://dx.doi.org/10.4238/2014.January.17.2

\begin{abstract}
We evaluated the genetic diversity of 77 clones of sugarcane used in crosses made by the Brazilian interuniversity network for the development of the sugar/energy sector (RIDESA) breeding program. Characterization of the genotypes was carried out at the ratoon stage, based on eight morphological traits and seven agronomic traits. Diversity analysis was carried out beginning with the Ward-Modified Location Model. The ideal number of groups was three. Groups 1, 2, and 3 were composed of 37, 21, and 19 accessions, respectively. Group 1 was formed entirely of commercial varieties (hybrids of advanced generations) and elite clones, with the exception of the old varieties 'Caiana Fita' and 'Cana Blanca' (hybrids of Saccharum officinarum). In general, group 2 had more divergent accessions regarding origin, including L60-14, NG57-6, TUC77-42, IN84-105 (hybrid of S. officinarum), and 28NG289 (species of $S$. robustum). Group 3 was formed entirely of commercial varieties and elite clones from the RIDESA program, with the exception of genotypes Co285 (India), Q124 (Australia) and VAT90-212 (unknown origin). The analysis based on the Ward-Modified Location Model
\end{abstract}


procedure resulted in an adequate and clearly discriminating grouping of sugarcane accessions, allowing the use of all the available information about the genotypes, in a mix of continuous and categorical variables.

Key words: Saccharum spp; Germplasm characterization; Genetic diversity; Multivariate analysis

\section{INTRODUCTION}

Sugarcane is cultivated in more than 100 tropical and subtropical nations and is of great economic importance due to the commercial value of its products, mainly sugar and ethanol. Furthermore, sugarcane has recently highlighted as a source of sustainable energy for the cogeneration of electricity and cellulosic ethanol from bagasse (Hofsetz and Silva, 2012).

Due to the increasing world demand for the production of biofuels, sugarcane production in Brazil has grown considerably in recent years, with the use of new agricultural areas, including regions with adverse edaphoclimatic conditions (Endres et al., 2010; Silva et al., 2012).

According to Waclawovsky et al. (2010), the average world yield is $80 \mathrm{t} / \mathrm{ha}$ and the theoretical maximum sugarcane yield is $380 \mathrm{t} / \mathrm{ha}$. The average yield of Brazilian varieties ( $68 \mathrm{t} / \mathrm{ha}$ in 2011) falls quite short of what can actually be achieved with the genetic potential of the crop, which emphasises the necessity of breeding programs in achieving this objective. To attain the desired level of production without incorporating large new areas, breeding programs should indicate increasingly productive clones that are better adapted to these new regions in the shortest time.

Since the success of the development of new varieties of sugarcane is associated with the ability to correctly choose the best individuals to be the progenitors of the new varieties, a better understanding of the genetic diversity between the clones used as progenitors is essential in defining the new crosses (Alwala et al., 2006; Santos et al., 2012). To achieve this objective, it is necessary to characterize the germplasm collection of the breeding program.

The process of germplasm collection characterisation, in addition to providing the basic data necessary for the breeding programs, has a strategic application in the evaluation of genetic resources (Mohammadi and Prasanna, 2003). Also, advances in the areas of computational technology, numerical taxonomy, and methods of multivariate statistics have contributed to the conservation of genetic resources, the formation of nuclear collections and the identification of possible duplicates (Ortiz et al., 2008), furthermore providing parameters for progenitor choice that enable a greater heterotic effect on the progeny and increasing the chance of obtaining transgressive genotypes in segregant generations.

The best method of numerical classification is the one that defines the most compact, well-separated groups (Crossa and Franco, 2004). Franco et al. (1998) proposed the Ward Modified Location Model (Ward-MLM) as a substitute for the Location Model procedure proposed by Lawrence and Krzanowski (1996). This method allows the definition of the optimal number of groups and the calculation of an average of the groups with a high level of precision, making use of all of the available information about the genotypes, whether they are continuous, binary, or multi-categorical variables (Crossa and Franco, 2004).

The objective of this work was to evaluate the genetic diversity between 77 clones of sugarcane used in crosses by the RIDESA breeding program, using the Ward-MLM method, to obtain new varieties of sugarcane. 


\section{MATERIAL AND METHODS}

\section{Plant material}

Seventy-seven clones of sugarcane belonging to the Active Germplasm Bank (AGB) of the Genetic Improvement Program of Sugarcane at Universidade Federal de Viçosa were used in this study, which integrates RIDESA (Table 1). AGB is composed of cultivated varieties, progenitors of commercial crosses, and old varieties. It is located in the municipality of Viçosa $\left(20^{\circ} 45^{\prime} \mathrm{S}, 42^{\circ} 52^{\prime} \mathrm{W}\right.$; altitude, $\left.648.74 \mathrm{~m}\right)$, in the state of Minas Gerais, Brazil.

AGB was implemented in 2009 in augmented blocks with two progenitors as controls (RB867515 and SP80-1816), with nine blocks of 15 plots each. The plots were constructed in furrows $3 \mathrm{~m}$ in length, which were spaced $1.4 \mathrm{~m}$ apart.

\section{Phenotypic characterization}

The characterization of the genotypes was carried out in August 2012, in the ratoon stage, 12 months after the last harvest, and was based on eight morphological traits and seven agronomic traits (Table 2).

\section{Statistical analyses}

The quantitative data was analyzed by restricted maximum likelihood (REML) and best linear unbiased prediction (BLUP), using the following statistical model: $\mathrm{y}=\mathrm{Xf}+\mathrm{Zg}+$ $\mathrm{Wb}+\mathrm{e}$, in which $\mathrm{y}$ is the vector of observations, where $\mathrm{y} \sim \mathrm{N}(\mathrm{XF}, \mathrm{V}), \mathrm{f}$ is the vector of the effects assumed as fixed (averages of controls and average of the principal treatment population), is the vector of the genotypic effects (assumed as random), where $g \sim N(0, G), G$ is the matrix of genetic covariance of the genotypes $G=A \hat{\sigma}_{g}^{2}$, is the vector of the environmental effects of the blocks (assumed as random), where $\mathrm{b} \sim \mathrm{N}\left(0, \mathrm{I} \hat{\sigma}_{b}^{2}\right)$, is the vector of errors or residuals (random), where $\mathrm{e} \sim \mathrm{N}(0, \mathrm{R}), \mathrm{R}$ is the matrix of residual covariance $\left(\mathrm{R}=\mathrm{I} \hat{\sigma}_{\mathrm{e}}^{2}\right), \mathrm{X}, \mathrm{Z}$ and $\mathrm{W}$ are the incidence matrices for said effects, and $\mathrm{V}=\mathrm{ZA} \hat{\sigma}_{\mathrm{g}}^{2} \mathrm{Z}^{\prime}+\mathrm{WI} \hat{\sigma}_{\mathrm{b}}^{2} \mathrm{~W}^{\prime}+\mathrm{I} \hat{\sigma}_{\mathrm{e}}^{2}$. In this study, the matrix $\mathrm{G}$ was assumed to be equal to $\mathrm{I} \hat{\sigma}_{\mathrm{g}}^{2}$, that is $G=I$, where $\mathrm{I}=$ identity matrix. The variance components $\hat{\sigma}_{\mathrm{g}}^{2}, \hat{\sigma}_{\mathrm{b}}^{2}$, and $\hat{\sigma}_{\mathrm{e}}^{2}$ correspond to the genotypic variance, block variance, and residual variance, respectively.

The diversity analysis was carried out beginning with the Ward-Modified Location Model with the use of the SAS software version 9.1.3 (SAS, 2002), starting with the qualitative variable mode and the average genotypic average of the quantitative variables estimated with the use of the SELEGEN-REML/BLUP software (Resende, 2007).

\section{Relationship coefficient}

After grouping, the coefficient of relationship (f) was obtained to investigate the relationship of the individuals within each group. Accordingly, the SAS software version 9.1.3 (SAS, 2002) was employed using the "proc inbreed" procedure. For the remote ancestors, $f$ was considered to be equal to zero, as suggested by Cox et al. (1985), and the coefficient of endogamy equal to zero was assigned to each genotype, considering the heterozygous trait of this crop (Deren, 1995). 
Table 1. Identification of the accessions, pedigree, and group into which each of the 77 sugarcane genotypes of the RIDESA/UFV germplasm bank were clustered.

\begin{tabular}{|c|c|c|c|c|}
\hline Group & Accession & Female parent & Male parent & Origin $^{a}$ \\
\hline 1 & Caiana Fita & S. officinarum & S. officinarum & Salinas, Brasil \\
\hline 1 & Cana Blanca & S. officinarum & S. officinarum & Cuba \\
\hline 1 & CB $47-355$ & POJ 2878 & Co413 & C. Goytacazes, Brasil \\
\hline 1 & IAC52-326 & Co419 & $?$ & IAC, Brasil \\
\hline 1 & RB001905 & $?$ & $?$ & UFAL, Brasil \\
\hline 1 & RB001913 & RB931602 & $?$ & UFAL, Brasil \\
\hline 1 & RB001914 & RB72454 & $?$ & UFAL, Brasil \\
\hline 1 & RB001922 & $?$ & $?$ & UFAL, Brasil \\
\hline 1 & RB00412 & $?$ & $?$ & UFAL, Brasil \\
\hline 1 & RB008004 & SP80-3480 & SP80-1836 & UFV, Brasil \\
\hline 1 & RB01406 & $?$ & $?$ & UFAL, Brasil \\
\hline 1 & RB72454 & CP53-76 & $?$ & UFAL, Brasil \\
\hline 1 & RB806043 & NA56-79 & $?$ & UFPR, Brasil \\
\hline 1 & RB825336 & H53-3989 & $?$ & UFSCar, Brasil \\
\hline 1 & RB825548 & F150 & ? & UFSCar, Brasil \\
\hline 1 & RB83102 & NA56-79 & SP70-1143 & UFAL, Brasil \\
\hline 1 & RB8317 & POJ 2878 & H56-6724 & UFAL, Brasil \\
\hline 1 & RB835089 & RB72454 & NA56-79 & UFSCar, Brasil \\
\hline 1 & RB835486 & L60-14 & ? & UFSCar, Brasil \\
\hline 1 & RB845197 & RB72454 & SP70-1143 & UFSCar, Brasil \\
\hline 1 & RB845257 & RB72454 & SP70-1143 & UFSCar, Brasil \\
\hline 1 & RB8495 & SP70-1143 & ? & UFAL, Brasil \\
\hline 1 & RB855035 & L60-14 & SP70-1284 & UFSCar, Brasil \\
\hline 1 & RB855036 & RB72454 & SP70-1143 & UFSCar, Brasil \\
\hline 1 & RB855113 & SP70-1143 & RB72454 & UFSCar, Brasil \\
\hline 1 & RB876030 & RB72454 & ? & UFPR, Brasil \\
\hline 1 & RB928064 & SP70-1143 & $\dot{?}$ & UFV, Brasil \\
\hline 1 & RB93509 & RB72454 & $?$ & UFAL, Brasil \\
\hline 1 & RB941537 & RB83160 & RB855035 & UFSCar, Brasil \\
\hline 1 & RB947501 & SP71-1406 & RB72454 & UFV, Brasil \\
\hline 1 & RB975950 & RB825548 & RB835486 & UFSCar, Brasil \\
\hline 1 & SP70-1143 & IAC $48 / 65$ & ? & Copersucar, Brasil \\
\hline 1 & SP71-3530 & $?$ & $?$ & Copersucar, Brasil \\
\hline 1 & SP77-5181 & HJ57-41 & $?$ & Copersucar, Brasil \\
\hline 1 & SP79-1011 & NA56-79 & Co775 & Copersucar, Brasil \\
\hline 1 & SP80-1816 & SP71-1088 & H57-5028 & Copersucar, Brasil \\
\hline 1 & SP83-2847 & HJ5741 & SP70-1143 & Copersucar, Brasil \\
\hline 2 & $28 \mathrm{NG} 289$ & S. robustum & ? & Coimbatore, Índia \\
\hline 2 & IAC87-3396 & Co 740 & SP70-1143 & IAC, Brasil \\
\hline 2 & IN84-105 & S. officinarum & ? & Indonésia \\
\hline 2 & L60-14 & CP52-1 & СР48-103 & Louisiana, USA \\
\hline 2 & NG57-6 & S. officinarum & S. officinarum & Coimbatore, India \\
\hline 2 & RB00507 & RB931530 & RB83594 & UFAL, Brasil \\
\hline 2 & RB00404 & SP79-2233 & $?$ & UFAL, Brasil \\
\hline 2 & RB721012 & Co331 & $?$ & UFAL, Brasil \\
\hline 2 & RB75126 & $\mathrm{C} 278$ & $?$ & UFAL, Brasil \\
\hline 2 & RB813804 & CP48-124 & $?$ & UFPB, Brasil \\
\hline 2 & RB835054 & RB72454 & NA56-79 & UFSCar, Brasil \\
\hline 2 & RB845210 & RB72454 & SP70-1143 & UFSCar, Brasil \\
\hline 2 & RB855156 & RB72454 & TUC71-7 & UFSCar, Brasil \\
\hline 2 & RB855206 & RB72454 & TUC71-7 & UFSCar, Brasil \\
\hline 2 & RB867515 & RB72454 & ? & UFV, Brasil \\
\hline 2 & RB925211 & RB855206 & $?$ & UFSCar, Brasil \\
\hline 2 & RB946903 & RB765418 & RB72454 & UFPR, Brasil \\
\hline 2 & SP80-1842 & SP71-1088 & H57-5028 & Copersucar, Brasil \\
\hline 2 & SP80-3280 & SP71-1088 & $\mathrm{H} 57-5028$ & Copersucar, Brasil \\
\hline 2 & TUC77-42 & CP71-321 & US72-19 & Tucuman, Argentina \\
\hline 2 & UVA & ? & ? & Salinas, Brasil \\
\hline 3 & $\mathrm{Co} 285$ & S. spontaneum & $?$ & Coimbatore, India \\
\hline 3 & Q124 & $\operatorname{Co3} 10$ & 54 N7096 & BSES, Austrália \\
\hline 3 & RB001906 & $?$ & ? & UFAL, Brasil \\
\hline
\end{tabular}




\begin{tabular}{|c|c|c|c|c|}
\hline Group & Accession & Female parent & Male parent & Origin $^{\mathrm{a}}$ \\
\hline 3 & RB001916 & $?$ & $?$ & UFAL, Brasil \\
\hline 3 & RB001921 & $?$ & $?$ & UFAL, Brasil \\
\hline 3 & RB00410 & SP80-1770 & RB75126 & UFAL, Brasil \\
\hline 3 & RB00416 & CB47-355 & ? & UFAL, Brasil \\
\hline 3 & RB00504 & ? & ? & UFAL, Brasil \\
\hline 3 & RB00509 & RB931530 & RB83594 & UFAL, Brasil \\
\hline 3 & RB01413 & ? & ? & UFAL, Brasil \\
\hline 3 & RB855046 & SP70-1143 & TUC71-7 & UFSCar, Brasil \\
\hline 3 & RB855536 & SP70-1143 & RB72454 & UFSCar, Brasil \\
\hline 3 & RB925345 & H59-1966 & ? & UFSCar, Brasil \\
\hline 3 & RB92606 & Q107 & RB72454 & UFAL, Brasil \\
\hline 3 & RB931555 & SP71-6113 & $?$ & UFAL, Brasil \\
\hline 3 & RB945961 & RB855206 & $?$ & UFSCar, Brasil \\
\hline 3 & RB956911 & RB855206 & RB855035 & UFPR, Brasil \\
\hline 3 & RB977619 & RB72454 & RB806043 & UFV, Brasil \\
\hline 3 & VAT90-212 & ? & ? & $?$ \\
\hline
\end{tabular}

aAC = Instituto Agronômico de Campinas; UFAL = Universidade Federal de Alagoas; UFSCar = Universidade Federal de São Carlos; UFV = Universidade Federal de Viçosa; UFPR = Universidade Federal do Paraná; UFPB = Universidade Federal de Pernambuco; BSES = Bureau of Sugar Experiment Stations. $?=$ parent/origin unidentified.

\begin{tabular}{|c|c|c|}
\hline Variables & Scale & Description \\
\hline \multicolumn{3}{|l|}{ Morphological $^{a}$} \\
\hline SR & $1-4$ & $(1=$ natural, $2=$ easy, $3=$ medium, $4=$ difficult $)$ \\
\hline LH & $1-4$ & $(1=$ absent, $2=$ few, $3=$ medium, $4=$ very many $)$ \\
\hline $\mathrm{BP}$ & $1-3$ & $(1=$ bud prominence $<1 \mathrm{~mm}, 2=2 \mathrm{~mm}, 3=3 \mathrm{~mm})$ \\
\hline BG & $1-3$ & $\left(1=\right.$ absent, $2=$ inclination $\angle 30^{\circ}, 3=\operatorname{among} 30^{\circ}$ and $\left.60^{\circ}\right)$ \\
\hline 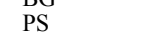 & $\begin{array}{l}1-3 \\
1-3\end{array}$ & $(1=$ absent, $2=$ diameter $\angle 1 \mathrm{~mm}, 3=$ among 1 and $2 \mathrm{~mm})$ \\
\hline $\mathrm{EP}$ & $1-4$ & $(1=$ absent, $2=1 / 4$ of stalk, $3=1 / 2,4>1 / 2)$ \\
\hline LA & $1-4$ & $(1=$ erect, $2=$ tip curve, $3=$ arched, $4=$ base curve $)$ \\
\hline \multirow{2}{*}{\multicolumn{3}{|c|}{ (1 - ausenit, 2 - silanower, 5 - - piorouna) }} \\
\hline & & \\
\hline $\mathrm{SH}$ & & Stalk height $(\mathrm{cm})$ \\
\hline SD & & Stalk diameter \\
\hline $\mathrm{SN}$ & & Stalk number ${ }^{\mathrm{c}}$ \\
\hline BRIX & & Brix \% \\
\hline IL & & Internode length $(\mathrm{cm})$ \\
\hline $\mathrm{L}+3$ & & Leaf +3 length $(\mathrm{cm})$ \\
\hline SW & & Stalk weight $(\mathrm{g})$ \\
\hline
\end{tabular}

${ }^{\mathrm{a}} \mathrm{SR}=$ Straw removal; $\mathrm{LH}=$ Leaf sheath hair; $\mathrm{BP}=$ Bud prominence; $\mathrm{BG}=$ Bending by excessive growth; $\mathrm{PS}=$ Piping of stalk; EP = Extension pith; LA = Leaf architecture and DC $=$ depth of channel. ${ }^{\mathrm{b}} \mathrm{All}$ of the agronomic variables were measured in three stalks in each plot. ${ }^{c}$ Total Number of stalks in a three-meter plot.

\section{RESULTS AND DISCUSSION}

In defining the number of groups, the ideal quantity defined by the Ward-MLM method was equal to three, since the risk profile associated with the likelihood ratio test showed the greatest increase in the logarithmic function of probability in group 3 (71.77) (Figure 1).

According to Gonçalves et al. (2009), the logarithmic function of probability precisely defines the number of groups, resulting in less subjective groupings. Different studies have demonstrated that the number of groups can vary greatly depending on the species, the number of accessions, and the type/quantity of variables evaluated (Ortiz et al., 2008; Gonçalves et al., 2009; Barbé et al., 2010; Cabral et al., 2010). 
In sugarcane, studies evaluating the genetic diversity have been conducted with the use of quantitative and qualitative traits, and/or with molecular markers (Da Silva et al., 2008; Oliveira et al., 2009; Duarte Filho et al., 2010; Dutra Filho et al., 2011; Sindhu et al., 2011; Santos et al., 2012; Santchurn et al., 2012; Perera et al., 2012). In these works, a high degree of genetic similarity between the genotypes has been found, resulting in the formation of few groups.

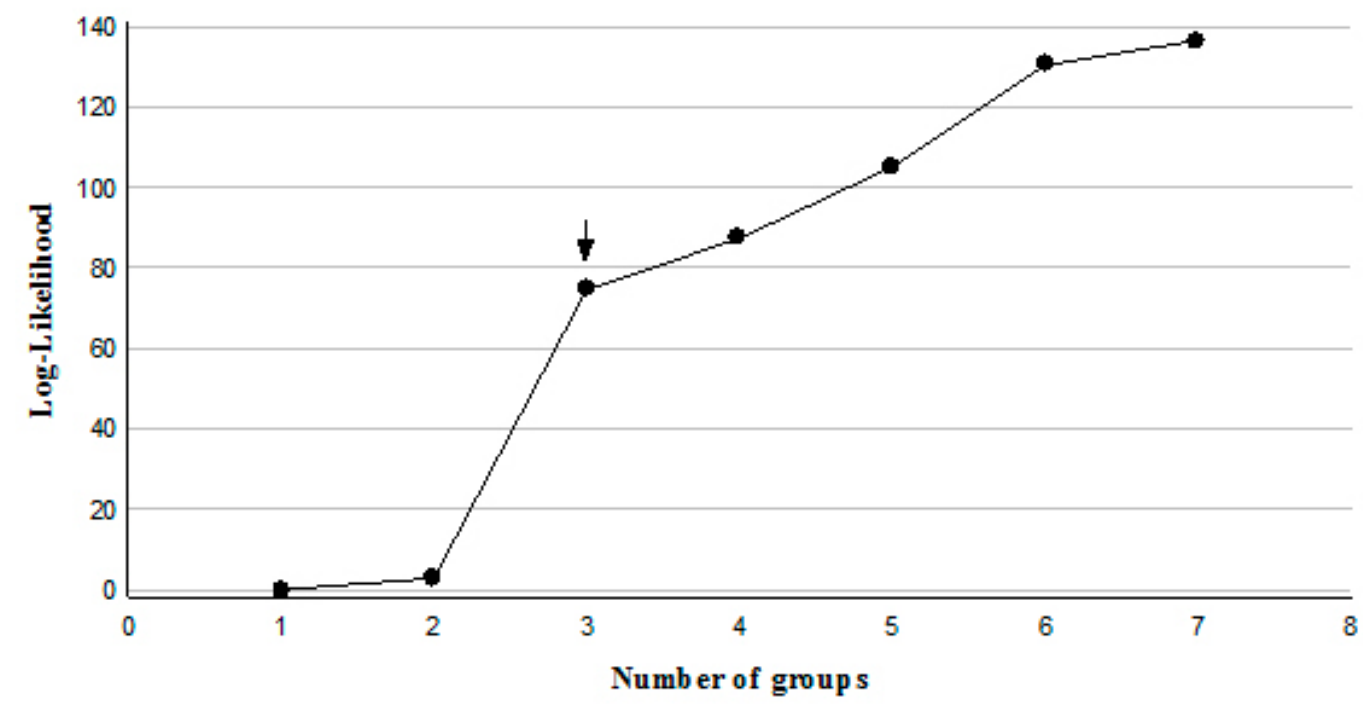

Figure 1. Graph expressing the logarithmic probability function (log-likelihood) according to the number of groups.

In the present study, the first two canonical variables obtained with the Ward-MLM explained $100 \%$ of the variation observed, permitting a satisfactory understanding of the genetic variability between the groups and between the clones of the same group. The formation of the three groups can be observed in the graphic representation of the first two canonical variables (Figure 2).

On the basis of the Mahalanobis distance matrix, groups 1 and 2 were the closest, with a distance of 14.75, while the greatest distance, 19.37, was found between groups 1 and 3 (Table 3).

The greatest dispersion of accessions in group 3 correlates with the genetic distance values between the groups. Greater variability within group 3 was noted via the graphic dispersion. Indeed, this was calculated by the averages of the coefficients of relationship between the individuals of the same group, in which, for groups 1,2 , and 3 , the average values of the coefficients of relationship $(f)$ were $0.0137,0.0094$, and 0.0037 , respectively.

Groups 1, 2 and 3 were composed of 37, 21, and 19 accessions, respectively. Group 1 was formed entirely of commercial varieties (hybrids of advanced generations) and elite clones, with the exception of the old varieties Caiana Fita and Cana Blanca (hybrids of $S$. of ficinarum). In general, group 2 showed more divergent accessions in regard to the origin, such as L60-14, NG57-6, TUC77-42, IN84-105 (hybrid of S. officinarum) and 28NG289 (species $S$. robustum). Group 3 was formed totally of commercial varieties and elite clones from the RIDESA program, with the exception of the genotypes Co285 (India), Q124 (Australia), and VAT90-212 (unknown origin) (Table 1). 


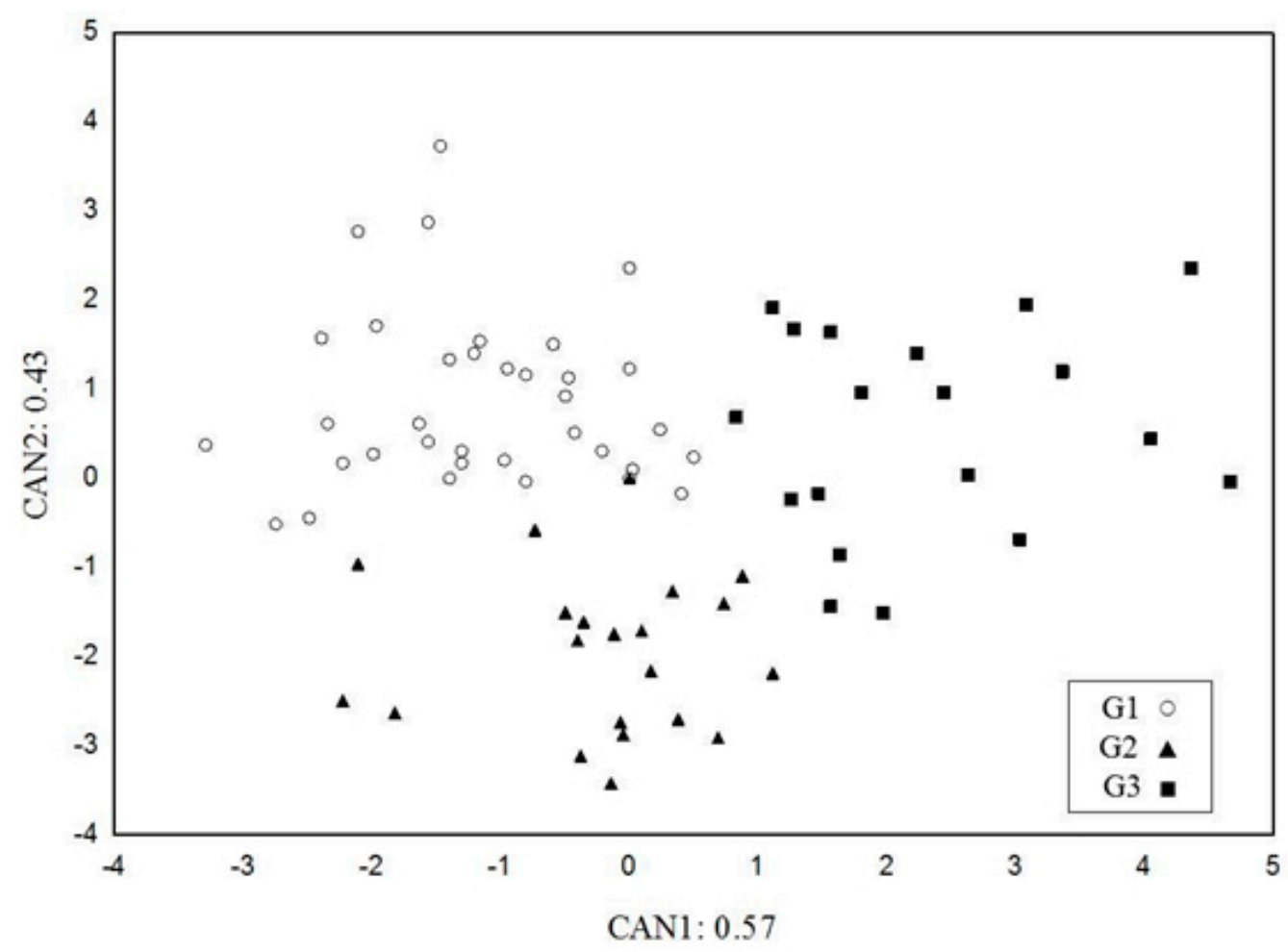

Figure 2. Representative graph of the first two canonical variables for the three groups formed by the Ward-MLM method.

Table 3. Mahalanobis distance between the groups formed by the Ward-MLM method.
\begin{tabular}{lccc}
\hline Groups & G1 & G2 & G3 \\
\hline G1 & - & 14.75 & 19.37 \\
G2 & 14.75 & - & 16.6 \\
G3 & 19.37 & 16.6 & - \\
\hline
\end{tabular}

With regard to the morphological variables, these displayed broad dispersion in the different classification categories, demonstrating great variability from the genotypes in relation to such traits (Table 4). It is important to highlight that the evaluation of morphological traits is performed in a subjective manner through the assignment of classes by the evaluator, which explains the greater variability encountered. However, due to the ease of measurement and agronomic importance, one can conclude that they are useful in the study of genetic diversity.

On the basis of the correlations of the agronomic traits with the two canonical variables, all of the traits evaluated showed considerable contributions to the genetic divergence, with the exception of SN the trait. The greatest magnitudes of correlation were observed between IL (CAN1), L+3 (CAN2), SW (CAN1), and SH (CAN1), with values of 0.8196, 0.7026, 0.6348 , and 0.6105 , respectively, demonstrating the importance of these variables for the study of genetic diversity in sugarcane (Table 5). 


\begin{tabular}{|c|c|c|c|}
\hline \multirow[t]{2}{*}{$\overline{\text { Variables }}$} & \multicolumn{3}{|c|}{ Groups } \\
\hline & G1 & $\mathrm{G} 2$ & G3 \\
\hline \multicolumn{4}{|l|}{ Straw removal } \\
\hline Natural & 1 & 1 & 1 \\
\hline Easy & 9 & 7 & 4 \\
\hline Medium & 21 & 7 & 9 \\
\hline Difficult & 6 & 6 & 5 \\
\hline \multicolumn{4}{|l|}{ Hair number } \\
\hline Absent & 10 & 16 & 10 \\
\hline Few & 16 & 3 & 8 \\
\hline Medium & 8 & 2 & - \\
\hline Very many & 3 & - & 1 \\
\hline \multicolumn{4}{|l|}{ Bud prominence } \\
\hline Prominence of $1 \mathrm{~mm}$ & 11 & 4 & 5 \\
\hline Prominence of $2 \mathrm{~mm}$ & 23 & 11 & 7 \\
\hline Prominence of $3 \mathrm{~mm}$ & 3 & 6 & 7 \\
\hline \multicolumn{4}{|c|}{ Bending by excessive growth } \\
\hline Absent & 31 & 14 & 14 \\
\hline Inclination $<30^{\circ}$ & 4 & 2 & 5 \\
\hline Between $30^{\circ}$ and $60^{\circ}$ & 2 & 5 & - \\
\hline \multicolumn{4}{|l|}{ Hollowing } \\
\hline Absent & 27 & 12 & 11 \\
\hline Diameter $<1 \mathrm{~mm}$ & 8 & 8 & 6 \\
\hline Between 1 and $2 \mathrm{~mm}$ & 2 & 1 & 2 \\
\hline \multicolumn{4}{|l|}{ Extension pith } \\
\hline Absent & 35 & 15 & 10 \\
\hline $1 / 4$ of stalk & 2 & 5 & 9 \\
\hline Between $1 / 4$ and $1 / 2$ & - & - & - \\
\hline$\geq 1 / 2$ & - & 1 & - \\
\hline \multicolumn{4}{|l|}{ Leaf architecture } \\
\hline Erect & 26 & 9 & 8 \\
\hline Tip curve & 9 & 11 & 9 \\
\hline Arched & 2 & 1 & 2 \\
\hline Base curve & - & _- & - \\
\hline \multicolumn{4}{|l|}{ Depth of channel } \\
\hline Absent & 21 & 14 & 9 \\
\hline Shallower & 14 & 6 & 9 \\
\hline Profound & 2 & 1 & 1 \\
\hline
\end{tabular}

Table 5. Means of agronomic traits (variables) for each of the three groups formed by the Ward-MLM method and correlation coefficient of the quantitative with the first two canonical variables (CAN).

\begin{tabular}{|c|c|c|c|c|c|}
\hline \multirow[t]{2}{*}{ Variables $^{\mathrm{a}}$} & \multicolumn{3}{|c|}{ Groups } & \multicolumn{2}{|c|}{$\mathrm{CAN}^{\mathrm{b}}$} \\
\hline & G1 & G2 & G3 & CAN1 & CAN2 \\
\hline IL & 6.37 & 6.43 & 6.68 & 0.8196 & 0.0632 \\
\hline $\mathrm{L}+3$ & 6.26 & 6.13 & 6.29 & 0.2128 & 0.7026 \\
\hline SN & 10.64 & 10.59 & 9.48 & -0.0685 & -0.0162 \\
\hline BRIX & 22.84 & 22.00 & 22.28 & -0.2014 & 0.3326 \\
\hline SH & 120.09 & 135.77 & 142.19 & 0.6105 & -0.3358 \\
\hline SW & 934.92 & 984.88 & 1094.1 & 0.6348 & -0.0434 \\
\hline $\mathrm{SD}$ & 37.89 & 37.81 & 38.02 & 0.3067 & 0.2793 \\
\hline
\end{tabular}

${ }^{a} \mathrm{IL}=$ internode length, $\mathrm{cm} ; \mathrm{L}+3=$ leaf +3 length, $\mathrm{cm} ; \mathrm{SN}=$ stalk number; BRIX = percentage of soluble solids in juice; $\mathrm{SH}=$ stalk height, $\mathrm{cm} ; \mathrm{SW}=$ stalk weight, $\mathrm{g} ; \mathrm{SD}=$ stalk diameter, $\mathrm{mm}$. ${ }^{\mathrm{b}}$ Correlation coefficients of canonical variables 1 (CAN1) and 2 (CAN2).

Considering the general genotypic average of each trait evaluated for the three groups formed by the Ward-MLM method (Table 5), it can be seen that the greatest averages for the traits 
SN and BRIX occurred in group 1. In contrast, the smallest averages for IL, SH, and SW were shown by the same group. For L+3, BRIX, and SD, the smallest averages were from group 2, and the smallest averages for $\mathrm{SN}$ were from group 3. Thus, for the quantitative traits evaluated, it can be seen that group 3 had the largest number of genotypes with superior averages in relation to the other groups, with the exception of SN and BRIX, whose averages from group 1 were superior.

The description of the data allocated within each group, for all of the quantitative variables, is presented in Figure 3. For IL, the amplitudes of the data were very similar between the three groups. However, the data from group 3 exhibited greater variation and more elevated averages. For $\mathrm{L}+3$, the amplitudes remained similar, and again, group 3 presented greater values with greater variation of the data. However, in this case, it was group 2 that had the smallest values (Figure 3).
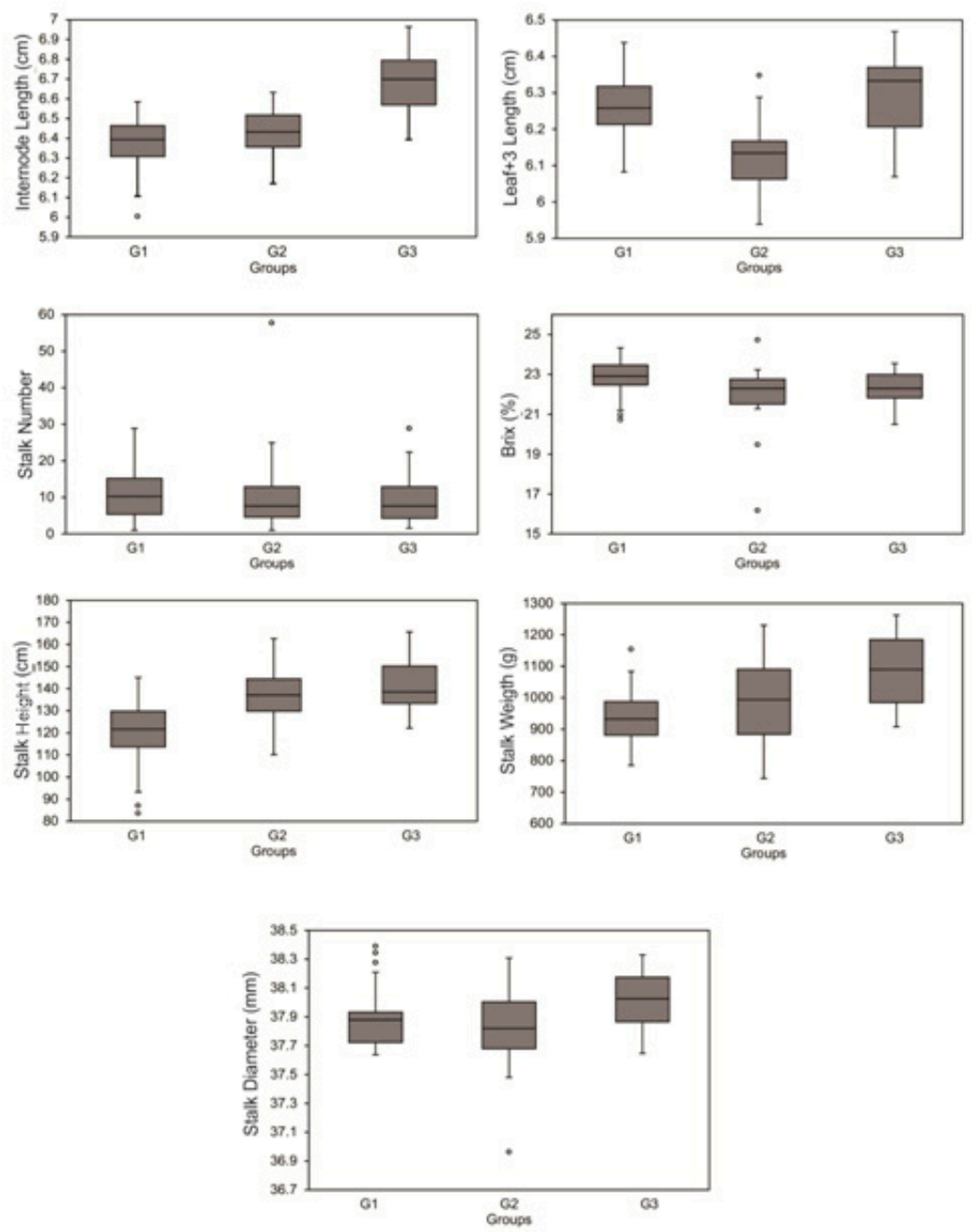

Figure 3. Box-plots showing variation of the data from the seven quantitative variables evaluated in the 77 accessions of sugarcane grouped into three groups by the Ward-MLM method. 
In relation to $\mathrm{SN}$ and BRIX, the genotypic averages were very similar between and within the groups, with a slight superiority for group 1 (Figure 3). It is important to highlight that the outliers for SN (57.7) and BRIX (16.17) in group 2 were obtained from genotype 28NG289. This genotype in particular is the only representative of the species $S$. robustum, and is characterized by a high number of small diameter stalks and low sucrose content in the juice.

The genotypic averages for SH and SW increased from group 1 to group 3. Group 2 had intermediate averages. The trend of similarity between the groups for these two traits was expected, since the Pearson correlation between these variables was $0.70(\mathrm{P}<0.01)$. Therefore, on average, it could be expected that a greater height would give rise to greater stalk weight. Ultimately, the trait SD showed similar averages between the groups, with a pronounced outlier (36.96) for group 2, once more arising from genotype 28NG289 (Figure 3).

Considering that the traits of greater agronomic interest in the current study were SN and BRIX, the genotypes that stood out in group 1 for SN were RB8495, RB001914, and RB845257, with genotypic averages of $28.88,25.83$, and 19.78 for stalks per plot, respectively. For BRIX, the prominent genotypes were RB001922 (24.34\%), RB825336 (24.26\%), and RB876030 (24.02\%). In group 2, as previously stated, the genotype with the greatest genotypic average for SN was clone 28NG289 (57.71), followed by clones RB00507 (24.97) and UVA (18.50). With regard to BRIX, the clones that stood apart were SP80-1842 (24.73\%), RB813804 (23.24\%), and RB00404 (23\%). With regard to SN in group 3, the genotypes with the greatest genotypic averages were the clones Co285 (28.85), RB00509 (22.38), and RB855536 (13.71). For BRIX, the clones RB925345 (23.55\%), RB945961 (23.55\%), RB855046 (23.40\%), and Q124 (23\%) had the highest genotypic averages.

The formation of groups is important in progenitor choice in breeding programs, since the new hybrid populations should be established on the basis of the magnitude of their dissimilarities and on the "per se" potential of the progenitors. The analysis strategy based on the Ward-MLM procedure resulted in an adequate and clearly discriminating grouping of accessions of sugarcane, allowing the use of all of the available information about the genotypes, in a mix of continuous and categorical variables. The Ward-MLM method has permitted the formation of compact, heterogeneous groupings in studies of snap beans, common bean, corn, Brassica rapa subsp. rapa L. and Capsicum spp. (Padilla et al., 2005; Ortiz et al., 2008; Barbé et al., 2010; Sudré et al., 2010; Cabral et al., 2010;). This technique is therefore an important statistical tool to be incorporated into sugarcane breeding programs to evaluate genetic diversity in germplasm banks, assisting in the definition of crossing strategies to increase efficiency in the generation of transgressive genotypes.

\section{ACKNOWLEDGMENTS}

Research supported by the Breeding Program for Sugarcane, at the Universidade Federal de Viçosa (PMGCA-UFV/RIDESA), the Conselho Nacional de Desenvolvimento Científico e Tecnológico - CNPq, the Coordenação de Aperfeiçoamento de Pessoal de Nível Superior - CAPES Fundação de Amparo à Pesquisa do Estado de Minas Gerais - FAPEMIG.

\section{REFERENCES}

Alwala S, Suman A, Arro JA and Veremis JC (2006). Target region amplification polymorphism (TRAP) for assessing genetic diversity in sugarcane germplasm collections. Crop Sci. 46: 448-455.

Barbé TD, Amaral AT, Gonçalves LSA and Rodrigues R (2010). Association between advanced generations and genealogy 
in inbred lines of snap bean by the Ward-Modified Location Model. Euphytica 173: 337-343.

Cabral PDS, Soares TCB, Goncalves LSA and Amaral AT (2010). Quantification of the diversity among common bean accessions using Ward-MLM strategy. Pesq. Agropec. Bras. 45: 1124-1132.

Cox TS, Kiang YT, Gorman MB and Rodgers DM (1985). Relationship between Coefficient of Parentage and Genetic Similarity Indexes in the soybean. Crop Sci. 25: 529-532.

Crossa J and Franco J (2004). Statistical methods for classifying genotypes. Euphytica 137: 19-37.

Da Silva CM, Mangolin CA, Mott AS and Machado MFPS (2008). Genetic diversity associated with in vitro and conventional bud propagation of Saccharum varieties using RAPD analysis. Plant Breed. 127: 160-165.

Deren CW (1995). Genetic base of US mainland sugarcane. Crop Sci. 35: 1195-1199.

Duarte Filho L, Silva P, Santos J and Barbosa G (2010). Genetic similarity among genotypes of sugarcane estimated by SSR and coefficient of parentage. Sugar Tech. 12: 145-149.

Dutra Filho JA, Melo LJOT, Resende LV and Anunciação Filho CJ (2011). Aplicação de técnicas multivariadas no estudo da divergência genética em cana-de-açúcar. Rev. Ciênc. Agron. 42: 185-192.

Endres L, Silva JV, Ferreira VM and Barbosa GVS (2010). Photosynthesis and water relations in Brazilian sugarcane. The Open Agric. J. 4: 31-37.

Franco J, Crossa J, Villasenor J and Taba S (1998). Classifying genetic resources by categorical and continuous variables. Crop Sci. 38: 1688-1696.

Gonçalves LS, Rodrigues R, do Amaral Junior AT, Karasawa M, et al. (2009). Heirloom tomato gene bank: assessing genetic divergence based on morphological, agronomic and molecular data using a Ward-modified location model. Genet. Mol. Res. 8: 364-374.

Hofsetz K and Silva MA (2012). Brazilian sugarcane bagasse: Energy and non-energy consumption. Biomass Bioenerg. 46: 564-573.

Lawrence CJ and Krzanowski WJ (1996). Mixture separation for mixed-mode data. Stat. Comput. 6: 85-92.

Mohammadi SA and Prasanna BM (2003). Analysis of genetic diversity in crop plants - Salient statistical tools and considerations. Crop Sci. 43: 1235-1248.

Oliveira KM, Pinto LR, Marconi TG, Mollinari M, et al. (2009). Characterization of new polymorphic functional markers for sugarcane. Genome 52: 191-209.

Ortiz R, Sevilla R, Alvarado G and Crossa J (2008). Numerical classification of related Peruvian highland maize races using internal ear traits. Genet. Resour. Crop. Ev. 55: 1055-1064.

Padilla G, Cartea ME, Rodriguez VM and Ordas A (2005). Genetic diversity in a germplasm collection of Brassica rapa subsp rapa L. from northwestern Spain. Euphytica 145: 171-180.

Perera MF, Arias ME, Costilla D and Luque AC (2012). Genetic diversity assessment and genotype identification in sugarcane based on DNA markers and morphological traits. Euphytica 185: 491-510.

Resende MDV (2007). Software SELEGEN-REML/BLUP: Sistema Estatístico e Seleção Genética Computadorizada via Modelos Lineares Mistos. Embrapa Florestas.

Santchurn D, Ramdoyal K, Badaloo MGH and Labuschagne M (2012). From sugar industry to cane industry: investigations on multivariate data analysis techniques in the identification of different high biomass sugarcane varieties. Euphytica 185: 543-558.

Santos JM, Duarte Filho LSC, Soriano ML and Silva PP (2012). Genetic diversity of the main progenitors of sugarcane from the RIDESA germplasm bank using SSR markers. Ind. Crop. Prod. 40: 145-150.

SAS Institute (2002). Software Version 9.1.3 of the SAS System for Windows. SAS Institute Inc, Cary, NC.

Silva PP, Soares L, Costa JG and Silva Viana L (2012). Path analysis for selection of drought tolerant sugarcane genotypes through physiological components. Ind. Crop. Prod. 37: 11-19.

Sindhu R, Govindaraj P, Balamurugan A and Appunu C (2011). Genetic diversity in sugarcane hybrids (Saccharum spp complex) grown in tropical India based on STMS markers. J. Plant Biochem. Biot. 20: 118-124.

Sudré CP, Goncalves LS, Rodrigues R, do Amaral Junior AT, et al. (2010). Genetic variability in domesticated Capsicum spp as assessed by morphological and agronomic data in mixed statistical analysis. Genet. Mol. Res. 9: 283-294.

Waclawovsky AJ, Sato PM, Lembke CG, Moore PH, et al. (2010). Sugarcane for bioenergy production: an assessment of yield and regulation of sucrose content. Plant Biotechnol. J. 8: 263-276. 